\title{
Ontogenetic variation in light interception, self-shading and biomass distribution of seedlings of the conifer Araucaria araucana (Molina) K. Koch
}

\author{
Variación ontogenética en la intercepción lumínica, autosombramiento y distribución de \\ biomasa en plántulas de la conífera Araucaria araucana (Molina) K. Koch
}

CHRISTOPHER H. LUSK ${ }^{1,2}$ *, DANIEL S. FALSTER ${ }^{3}$, MANUEL PÉREZ-MILLAQUEO $^{1}$ \& ALFREDO SALDAÑA ${ }^{1}$

\author{
${ }^{1}$ Departamento de Botánica, Universidad de Concepción, Casilla 160-C, Concepción, Chile \\ ${ }^{2}$ Current address: Department of Biological Sciences, Macquarie University, NSW 2109, Australia \\ ${ }^{3}$ Department of Biological Sciences, Macquarie University, NSW 2109, Australia; \\ * e-mail for correspondence: clusk@bio.mq.edu.au
}

\begin{abstract}
One of the factors thought to contribute to ontogenetic declines in plant growth rates is diminishing light interception efficiency, as a result of the difficulties of avoiding self-shading among a growing number of leaves, and by stems. The effects of plant size on self-shading and light interception have rarely been quantified, however. We used a three-dimensional digitising system to construct virtual models of the architecture of Araucaria araucana seedlings 71 to $358 \mathrm{~mm}$ tall, and modelled their light interception in the forest understorey using the program YPLANT. We also analyzed seedling allometry, to determine the combined effects of biomass distribution and self-shading on total light interception. Average light interception efficiencies calculated for A. araucana $(29 \%)$ were the lowest reported for rainforest tree seedlings, reflecting the limitations imposed by short leaves, lack of petioles and an inability to develop planar foliage geometry on branches. Total light interception was related to seedling leaf area by an exponent of 0.735 , reflecting increasing self-shading as seedlings grew bigger. However, because leaf area was related to seedling mass by an exponent of 1.24 , light interception scaled nearly isometrically ( 0.91 power) with seedling mass. This resulted from taller plants having proportionally thinner stems, and a smaller fraction of their biomass in roots. Thus, an ontogenetic increase in self-shading in A. araucana is largely offset by allocation changes which increase leaf area ratio as seedlings grow bigger. These mechanisms conserving the relationship of light interception with plant mass seem likely to be restricted to species with long-lived leaves, growing in humid situations protected from wind stress. In open habitats, where wind and drought stress likely make such allocation patterns less feasible, the role of self-shading in ontogenetic declines in relative growth rate may be more evident.
\end{abstract}

Key words: allocation, allometry, FLORADIG, leaf area ratio, virtual plants, YPLANT.

\section{RESUMEN}

La caída en la eficiencia de intercepción de la luz es considerada como uno de los factores responsables del declive ontogenético en las tasas de crecimiento relativo de las plantas, debido a la dificultad de evitar el autosombramiento entre un creciente número de hojas. Sin embargo, rara vez se ha cuantificado el efecto de tamaño de las plantas sobre el autosombramiento y la eficiencia en intercepción de la luz. Utilizamos un sistema de digitalización para construir modelos virtuales tridimensionales de la arquitectura de plántulas 71$358 \mathrm{~mm}$ de alto de la conífera Araucaria araucana, y modelamos su intercepción de la luz en el sotobosque mediante el programa YPLANT. Analizamos además la alometría de las plántulas para determinar los efectos combinados de la distribución de biomasa y el autosombramiento sobre la intercepción total de luz a nivel de la planta entera. La eficiencia promedio de intercepción de la luz de A. araucana (29 \%) fue la más baja documentada para plántulas de especies de bosques húmedos, reflejando las limitaciones impuestas por hojas cortas, carencia de pecíolos, y la incapacidad de desarrollar follaje plagiotrópico. La intercepción total de luz por las plántulas fue proporcional al área foliar ${ }^{0,735}$, producto de un aumento en el autosombramiento en función del tamaño. Sin embargo, debido a la relación del área foliar con la potencia 1,24 de la masa de las plántulas, la intercepción de luz se acercó a la proporcionalidad directa (exponente 0,91) con la masa. Este patrón fue producto de la relativa delgadez de los tallos de las plántulas grandes, y su baja proporción de biomasa radicular. Por tanto, el declive ontogenético en la eficiencia de intercepción de la luz fue en gran 
medida compensada por cambios de asignación que aumentaron la superficie foliar de las plántulas grandes. Estos mecanismos que conservaron la relación de la ganancia potencial de carbono con la masa de las plántulas probablemente serán vistos solamente en especies con hojas muy longevas, en hábitats húmedos con poco viento. En ambientes abiertos, donde los estrés por sequía y viento podrían seleccionar en contra tales patrones de asignación, es probable que se evidencie más claramente el rol del autosombramiento en los declives ontogenéticos en la tasa de crecimiento relativo.

Palabras clave: alometría, asignación, área foliar, FLORADIG, plantas virtuales, YPLANT.

\section{INTRODUCTION}

Relative growth rates of plants are negatively correlated with size, a pattern evident both in comparisons across species, and during ontogeny (Hunt 1982, Niklas 1994). Although there have been recent attempts to link this pattern to vascular constraints on metabolic rates (Enquist et al. 1999, Niklas \& Enquist 2001), plant ecologists have identified sizerelated variation in a number of structural and architectural traits as possible causes of ontogenetic growth trends. As juvenile plants grow bigger, the ratio of foliage area to plant mass (leaf area ratio) often decreases, as a result of the foliage turning over faster than stem tissue, and declining specific leaf area (Walters et al. 1993, Poorter 1999, Lusk 2004). It has been argued that maintenance of mechanical stability will also require an increasing allocation to stem tissue (and hence less to foliage) as plants grow taller (Givnish 1988), although in reality this is rarely if ever seen in juvenile trees growing in sheltered understories (Kohyama 1987, Niklas 1995, Akasaka \& Tsuyuzaki 2005). In addition to a reduction in leaf area ratio, there is likely to be less light interception per unit leaf area, as a result of increasing self-shading among the growing number of leaves, as well as shading of leaves by stems (Givnish 1988, Falster \& Westoby 2003).

Although self-shading seems an inevitable consequence of growth, the effects of plant size on light interception efficiency have rarely been quantified. In the only such study that we are aware of, Niinemets et al. (2005) reported that mature trees of the conifer Agathis australis had lower light interception efficiency than saplings. Self-shading seems likely to be especially problematic for plants with small and sessile leaves, more so in species that accumulate many leaf cohorts e.g. some conifers. Simulations by Takenaka (1994) showed that light interception efficiency of orthotropic shoots was positively related to the length of both the petiole and the lamina, and a comparison of 38 woody species also found that leaf size was positively correlated with light interception efficiency (Falster \& Westoby 2003). Petiole twisting permits some plants to ameliorate self-shading by repositioning leaves as they become shaded by newer ones (Gálvez \& Pearcy 2003), but this option is not open to sessile-leaved species.

Here we report ontogenetic variation in selfshading and light interception efficiency in seedlings of the temperate South American conifer Araucaria araucana, which has small, sessile leaves and can accumulate as many as 25 leaf cohorts (Lusk 2001). Digitizing technology developed during the last 15 years greatly facilitates the task of quantifying plant architecture in three dimensions (Room et al. 1996, Sinoquet et al. 1998), and the program YPLANT (Yang \& Pearcy 1996) enables light interception of branches or whole plants to be modelled. Linking these two tools enables rapid processing of plants with large numbers of leaves (Falster \& Westoby 2003): we used this approach to analyse light interception by $A$. araucana seedlings in forest understorey environments in south-central Chile. We also quantified biomass distribution of seedlings, to determine the net effect of allocation and selfshading on the allometry of light interception.

\section{MATERIAL AND METHODS}

\section{Study area}

Seedlings were obtained from second-growth rainforest stands located at ca. $850 \mathrm{~m}$ of altitude on the western slopes of Cordillera de Nahuelbuta (37 $41^{\prime}$ S, $73^{\circ} 12^{\prime} \mathrm{W}$ ), in the Chilean coast range. Mean annual precipitation is $\leq$ $2,500 \mathrm{~mm}$, with a marked summer minimum, 
and mean annual temperature is ca. $12.5^{\circ} \mathrm{C}$ (Almeyda \& Sáez 1958, di Castri \& Hajek 1976). The main tree species accompanying Araucaria araucana were Nothofagus dombeyi Mirb. Oerst (Nothofagaceae), Drimys winteri J.R. Forst. \& G. Forst. (Winteraceae), Gevuina avellana Mol. (Proteaceae), Lomatia dentata (Ruiz \& Pav.) R. Br. and Luma apiculata (DC) Burret (Myrtaceae).

\section{Field sampling}

At 20 points along a walking track through the forest, we chose the nearest healthy-looking $A$. araucana seedling in the height range of interest $(5-35 \mathrm{~cm})$. Seedlings that had suffered major damage by herbivores or branchfalls were omitted. A Nikon Coolpix digital camera (Nikon Corporation, Japan) with a $182^{\circ}$ fisheye adapter was used to take a hemispherical photograph directly above each seedling, orienting the top of the camera towards north. Analysis of hemispherical photos indicated that canopy openness above the selected seedlings ranged from 2 to $10 \%$. Each seedling was then excavated carefully, removing a sod of sufficient width and depth to include the root system, after cutting through any intruding coarse roots from neighbouring plants. The seedling was transplanted to a pot of sufficient size to accommodate the excavated sod, and the seedling's orientation was indicated by marking the former position of north on the side of the pot. Pots were watered thoroughly and immediately transported to Universidad de Concepción.

\section{Digitizing}

The three-dimensional leaf arrangement of each seedling was recorded using a FASTRAK ${ }^{\circledR}$ 3D-digitizer (Polhemus, Colchester, Vermont, USA), in conjunction with the software package FLORADIG (CSIRO Entomology, Brisbane, Australia). The digitizer includes a magnetic signal receiver and pointer, allowing the user to record the 3D spatial co-ordinates of the pointer within a hemisphere of $3 \mathrm{~m}$ diameter from the receiver. Individual plants are reconstructed virtually by recording a series of point co-ordinates, and the relevant connectivity between points. Stem segments (and petioles, if present) are characterized by their elevation angle, azimuth, length and diameter. Individual leaves are characterized by their length together with the azimuth and elevation angle of two vectors on the lamina surface. The time required to digitize individual seedlings of A. araucana ranged from 2 to $4 \mathrm{~h}$, depending on the number of leaves. Although still time-consuming, the methods described here represent a marked acceleration of data collection, compared with the manual methods used to quantify architecture in other studies using the YPLANT software.

\section{Architectural model}

The YPLANT software (Pearcy \& Yang 1996) was used to estimate light interception for a single summer's day (1 January). The 3D description of leaf arrangement recorded for each seedling in FLORADIG was converted to the appropriate YPLANT format using a program written in the $\mathrm{C}$ programming language. YPLANT inputs are the geometry of leaf arrangement, a description of leaf shape, physiological parameters describing leaf photosynthetic capacity and a description of canopy structure above the plant to permit estimation of the light regime (normally provided by hemispherical photography). A solar movement submodel allows estimation of photon flux density (PFD: $\mu \mathrm{mol}$ photons $\mathrm{m}^{-2} \mathrm{~s}^{-}$ 1) incident on each leaf surface at different times of day. A submodel for potential photosynthesis allows the resulting assimilation rate to be estimated, given a PFD response curve, although we do not report this information here. Full details of the model can be found in Pearcy \& Yang (1996), and additional verification is provided by Pearcy \& Yang (1998) and Valladares \& Pearcy (1998).

Output from YPLANT includes a quantification of leaf projection and display (the amount of leaf area facing a particular direction), as well as estimates of light capture and potential carbon assimilation rate throughout different periods of the day. Variation in architectural traits (e.g. leaf angle) is manifested as variation as leaf display. In turn, leaf display determines light capture and hence potential photosynthesis. We considered the effect of architectural traits on both leaf display and light interception in order to understand their consequences for potential carbon gain. 
Quantifying leaf projection, display and selfshading

Leaf projection efficiency (PE) is the amount of leaf area projected towards a particular direction as a fraction of total leaf area, whether or not it is visible from that direction. $\mathrm{PE}$ is always $<1$ because most leaves are not face-on towards any given direction. Leaf display efficiency (DE) is the proportion of the plant's total leaf area seen when looking at the plant from that direction, i.e. taking leaf overlap into account. Logically, DE in the direction of the sun determines seedling direct light capture per unit area. PE and DE were calculated for each of 160 directions (20 angle classes $\mathrm{x}$ eight azimuth classes), spanning the entire hemisphere. Self-shading is measured here as the proportional reduction in leaf projection by leaf overlap, $\mathrm{SS}=(\mathrm{PE}-\mathrm{DE}) / \mathrm{PE}$. Average self-shading was calculated for each individual by averaging SS across all 160 angle and azimuth classes. Note that average selfshading is not weighted by the angular distribution of actual PFD over the hemisphere, as derived from the hemispherical photograph.

\section{Light interception}

Total light interception (direct and diffuse) by each seedling on 1 January in its original light environment was simulated in YPLANT. Light interception efficiency can be calculated as the ratio of light intercepted by the plant to that which would be captured by a horizontal plane of the same area as the plant's total foliage surface, in the same light environment. This index can give nonsensical figures $>1.0$ at low solar angles very early or very late in the day, if a plant has some leaves oriented at steep angles. However, light interception efficiency averaged over the day invariably gave plausible figures $<1.0$. As YPLANT has no function for simulating clouds, all simulations are carried out on "clear" days, and direct light dominates the estimated light regimes that seedlings were subjected to.

\section{Biomass harvesting}

After digitising, seedlings were separated into leaf, stem and root fractions. Fractions were weighed after drying for $72 \mathrm{~h}$ at $65^{\circ} \mathrm{C}$.

\section{Statistical analysis}

We used the statistical package (S)MATR (Falster et al. 2003) to examine major axis relationships among seedling mass, leaf area, light interception and $\mathrm{SS}_{\mathrm{AV}}$. This package computes standardised major axis, which, in contrast to least squares (or "model I") regression, minimises variance from the line in both dimensions, $x$ and y (Sokal \& Rohlf 1995, Warton \& Weber 2002). This is important when the primary concerns are the slope and/or intercept of a relationship (such as in allometric studies), rather than testing for a significant correlation or predicting one variable from another. Use of least squares regression will give misleading estimates of the slope of such relationships when correlation coefficients are low (Falster et al. 2003).

\section{RESULTS}

Light interception efficiencies of individual plants ranging from 18 to $57 \%$, with an average of $29 \%$. The total amount of light intercepted by seedlings was related to seedling leaf area by an exponent of 0.735 (Fig. 1A), indicating declining light interception efficiency with increasing size. The ontogenetic decline in light interception efficiency was linked to a significant positive relationship of self-shading with seedling leaf area (Fig. 1B).

Despite the ontogenetic trend in selfshading, total light interception was almost directly proportional to seedling mass, as the scaling exponent was close to 1.0 (Fig. 1C). This result was not significantly influenced by variation in the total daily PFD reaching seedlings, which was not correlated with plant height ( $\mathrm{r}=0.092, \mathrm{P}=0.70$; data not shown). Instead, it arose from leaf area increasing more than proportionally with seedling mass (exponent 1.24), meaning that larger seedlings were proportionally leafier than small seedlings (Fig. 1D). As specific leaf area was not correlated with seedling height $(P=0.69)$, the disproportionate ontogenetic increase in leaf area was a function of increasing leaf mass fraction, as a result of a decreasing root mass fraction (Fig. 1E, and negligible increases in stem diameter as plants grew taller (Fig. 1F). 

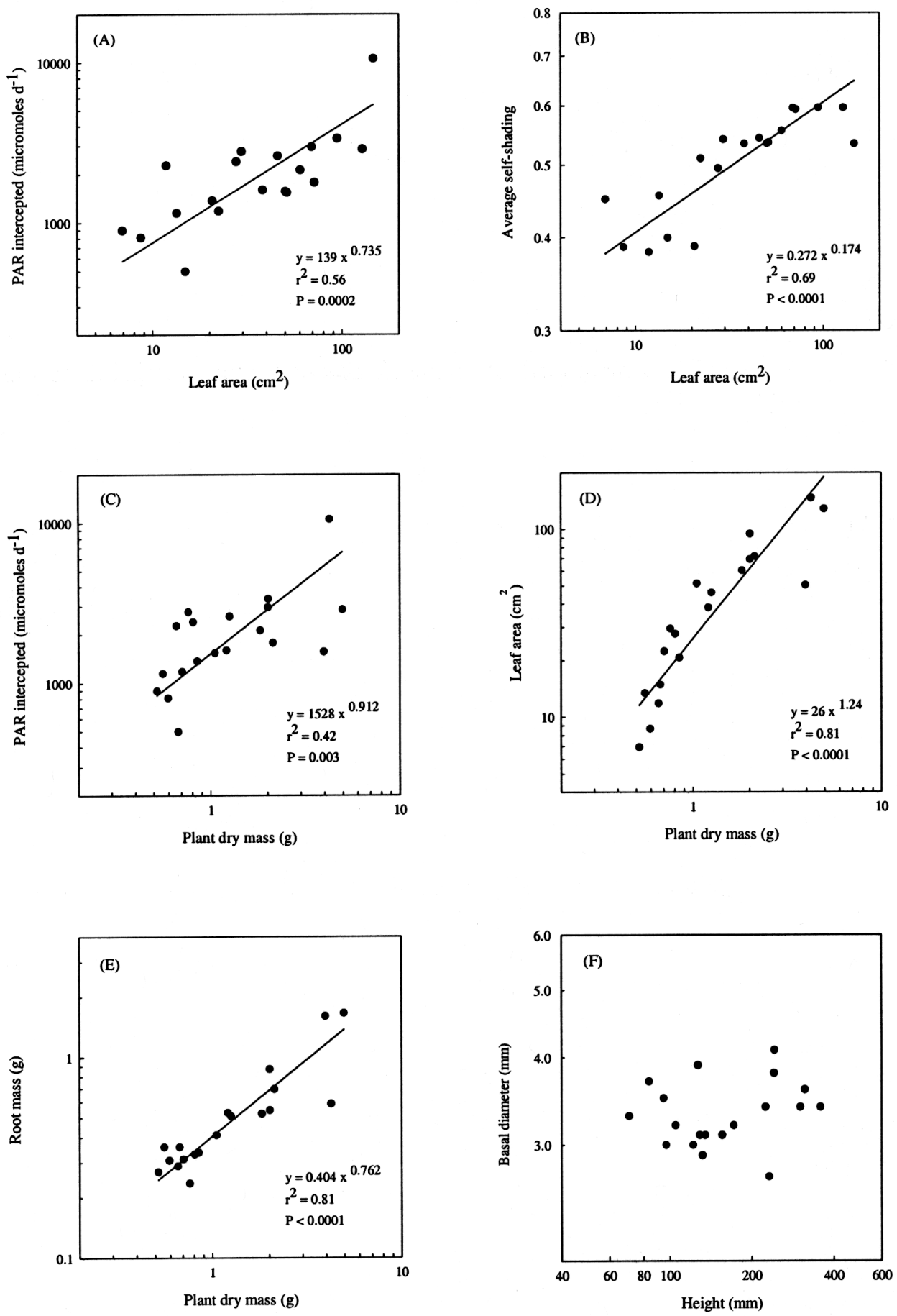

Fig. 1: Allometry and light interception of Araucaria araucana seedlings in a forest understorey, Cordillera de Nahuelbuta, Chile. (A) Relationship of total light interception with leaf area. (B) Relationship of self-shading with seedling leaf area. (C) Relationship of total light interception with seedling mass. (D) Scaling of leaf area with seedling mass. (E) Scaling of root mass with seedling mass. (F) Scaling of basal diameter with seedling height $(\mathrm{P}=0.42)$.

Alometría e intercepción lumínica de plántulas de Araucaria araucana en un sotobosque, Cordillera de Nahuelbuta. (A) Relación entre la intercepción total de luz y el área foliar de plántulas. (B) Relación entre autosombramiento y biomasa de plántulas. (C) Relación entre intercepción total de luz y biomasa de plántulas. (D) Relación del área foliar con biomasa total de plántulas. (E) Relación de la biomasa radicular con la biomasa total de plántulas. (F) Relación del diámetro basal con la altura de plántulas $(\mathrm{P}=0,42)$. 


\section{DISCUSSION}

The average light interception efficiency of Araucaria araucana (29\%) is one of the lowest calculated for any rainforest tree species using YPLANT. Pearcy et al. (2004) reported light interception efficiencies of 0.43-0.64 for juveniles of 11 sympatric species of Psychotria in a neotropical rainforest. At the same site, Valladares et al. (2002) reported corresponding figures of 0.3-0.83 in a survey of 24 understorey species spanning a wide range of taxa and growth forms. The generally low light interception efficiency of $A$. araucana probably reflects the limitations imposed by short leaves and lack of petioles, meaning that foliage is displayed within a narrow cylinder around each stem (Takenaka 1994), with no scope for repositioning or reorienting leaves to reduce self-shading (Gálvez \& Pearcy 2003). We are not aware of studies of light interception data by seedlings of any other broadleaved conifers, using this technology. However, seedlings of evergreen conifers from southern temperate forests generally have lower relative growth rates than their angiosperm counterparts (Read 1995, Lusk et al. 1997), which may be related in part to differences in light interception efficiency.

Although YPLANT assumes parallel solar beam geometry and therefore does not include penumbral effects, this omission is unlikely to have much impact on calculations of light interception by seedlings. Stenberg (1995) simulated the impact of penumbral effects on light interception and photosynthesis of Pinus sylvestris L. shoots. She found that the shading of one shoot by another $>250 \mathrm{~mm}$ away was dominated by penumbral effects, but that the assumption of parallel solar beam geometry within a shoot did not lead to serious underestimates of the rate of photosynthesis.

The inability of $A$. araucana to develop planar foliage geometry on branches is one of the factors driving the ontogenetic increase in self-shading (Fig. 1B). Before seedlings develop branches, self-shading is a function of internode, petiole and lamina dimensions (Takenaka 1994). As seedlings begin to ramify, species developing plagiotropic, rather than orthotropic, branches can be expected to undergo a less dramatic increase in self-shading (Givnish 1988). Plagiotropic axes, which minimize overlap of leaves on the same shoot by arranging foliage in a single horizontal plane, are common among shade-tolerant rainforest plants (King \& Maindonald 1999). We note that although Grosfeld et al. (1999) describe branches of $A$. araucana as "plagiotrophic", they apparently refer to the approximately planar pattern of ramification, rather than the arrangement of leaves around the stem. Niinemets et al. (2005) found that juvenile foliage of the conifer Agathis australis had a more planar geometry than adult foliage, and that this was one factor contributing to light interception differences between adult and juvenile trees.

Changes in biomass distribution largely neutralized the potential negative impact of increasing self-shading on total carbon gain potential. Despite the ontogenetic trend in selfshading, calculated total light interception was almost isometric with seedling mass (Fig. 1C), as a result of the unexpected scaling of leaf area with $>1.0$ power of seedling mass (Fig. 1D). It is not unusual for seedlings of shadetolerant rainforest species to maintain a stable leaf area ratio for several years, mainly because their long leaf lifespans enable the accumulation of many leaf cohorts (Lusk 2004). Exceptionally long leaf lifespans of $>25$ years have been recorded on semi-shaded juvenile trees (not seedlings) of A. araucana (Lusk 2001). However, the resulting similarity of turnover rates of foliage and woody tissues seedlings is not a sufficient explanation of the ontogenetic increase in leaf area ratio evident in A. araucana (Fig. 1D). One of the other factors contributing to this pattern was a striking departure of seedling stem dimensions from geometric similarity, with taller stems being little or no wider than short stems (Fig. 1F). Seedling and sapling stems often approximate geometric similarity (i.e., diameter and height scaling in direct proportion e.g. Kohyama 1987, Niklas 1995, Akasaka \& Tsuyuzaki 2005). However, there have been previous reports of height increasing proportionally faster than diameter in juvenile trees growing in the shaded understories of humid forests (King 1990), presumably reflecting strong selection pressure to minimize height growth costs in such habitats (King 1990), and the viability of low safety margins because of protection from wind (Niklas 1995). 
Declining root allocation is the other factor underlying the ontogenetic increase in leaf area ratio, as root mass scaled as roughly the $3 / 4$ power of plant mass (Fig. 1E), presumably reflecting low evaporative demands and plentiful soil moisture in this cool, sheltered rainforest environment. A similar pattern has been reported previously in juveniles of shadetolerant rainforest evergreens (Lusk 2004).

In conclusion, despite the increasing selfshading determined by the leaf and crown traits of A. araucana, growth brings only a slight decline in the light capture potential of seedlings, because of their increasing leaf area ratio (Fig. 1D). This strategy is likely to be confined to humid, shady environments. In open habitats where evaporative demands are much higher, and the upper soil horizons can dry out quickly, a deeper root system is likely be selected for ( $\mathrm{Paz} 2003$ ), and wind stress is likely to favour higher safety margins and stem dimensions closer to geometric similarity (Niklas 1995). In open habitats, therefore, the more limited scope for allocation adjustments conserving the relationship of light interception to plant mass may result in a more evident relationship between self-shading and ontogenetic declines in relative growth rate.

\section{ACKNOWLEDGMENTS}

We thank FONDECYT for funding through grant 1030811, and Lohengrin Cavieres for his comments on the manuscript.

\section{LITERATURE CITED}

AKASAKA M \& S TSUYUZAKI (2005) Tree seedling performance in microhabitats along an elevational gradient on Mount Koma, Japan. Journal of Vegetation Science 16: 647-654.

ENQUIST BJ, GB WEST, EL CHARNOV \& JH BROWN (1999) Allometric scaling of production and life history variation in vascular plants. Nature 401: 907-911.

FALSTER DS \& M WESTOBY (2003) Leaf size and angle vary widely across species: What consequences for light interception? New Phytologist 158: 509-525.

FALSTER DS, DI WARTON \& IJ WRIGHT (2003) (S)MATR: Standardised major axis tests and routines. Version 1.0; http://www.bio.mq.edu.au/ ecology/SMATR

GÁLVEZ D \& RW PEARCY (2003) Petiole twisting in the crowns of Psychotria limonensis: implications for light interception and daily carbon gain. Oecologia 135: 22-29.

GROSFELD J, D BARTHELEMY \& C BRION (1999) Architectural variations of Araucaria araucana (Molina) K. Koch (Araucariaceae) in its natural habitat. In: Kurmann MH \& AR Hemsley (eds) The evolution of plant architecture: 109-122. Royal Botanic Gardens, Kew, United Kingdom.

HUNT R (1982) Plant growth curves. Edward Arnold, London, United Kingdom. 248 pp.

GIVNISH TJ (1988). Adaptation to sun and shade: a whole-plant perspective. Australian Journal of Plant Physiology 15: 63-92.

KING DA (1990) Allometry of saplings and understorey trees of a Panamanian forest. Functional Ecology 4: 27-32.

KOHYAMA T (1987) Significance of architecture and allometry in saplings. Functional Ecology 1: 399404.

LUSK CH (2001) Leaf life spans in some conifers of the temperate rain forests of South America. Revista Chilena de Historia Natural 74: 711-718.

LUSK CH (2004) Leaf area and growth of juvenile temperate evergreens in low light: species of contrasting shade tolerance change rank during ontogeny. Functional Ecology 18: 820-828.

LUSK CH, O CONTRERAS \& J FIGUEROA (1997) Growth, biomass allocation and plant nitrogen concentration in Chilean temperate rainforest tree seedlings: effects of nutrient availability. Oecologia 109: 49-58

NIINEMETS Ü, A SPARROW \& A CESCATTI (2005) Light capture efficiency decrease with increasing tree age and size in the southern hemisphere gymnosperm Agathis australis. Trees 19: 177-190.

NIKLAS KJ (1994) Plant allometry: the scaling of form and process. University of Chicago Press, Chicago, Illinois, USA. 395 pp.

NIKLAS KJ (1995) Size-dependent allometry of tree height, diameter and trunk-taper. Annals of Botany 75: 217-227.

NIKLAS KJ \& BJ ENQUIST (2001) Invariant scaling relationships for interspecific plant biomass production rates and body size. Proceedings of the National Academy of Sciences USA 98: 2922-2927.

PAZ H (2003) Root/shoot allocation and root architecture in seedlings: variation among forest sites, microhabitats, and ecological groups. Biotropica 35: 318-332.

PEARCY RW \& W YANG (1996) A three-dimensional crown architecture model for assessment of light capture and carbon gain by understory plants. Oecologia 108: 1-12.

PEARCY RW \& W YANG (1998) The functional morphology of light capture and carbon gain in the Redwood forest understorey plant Adenocaulon bicolor Hook. Functional Ecology 12:543-552.

PEARCY RW, F VALLADARES, SJ WRIGHT \& E LASSO (2004) A functional analysis of the crown architecture of tropical forest Psychotria species: do species vary in light capture efficiency and consequently in carbon gain and growth? Oecologia 139: 163-167.

POORTER L (1999) Growth rate responses of 15 rainforest tree species to a light gradient: the relative importance of morphological and physiological traits. Functional Ecology 13: 396-410.

READ J (1995) The importance of comparative growth rates in determining the canopy composition of Tasmanian rainforest. Australian Journal of Botany 43: $243-271$ 
ROOM PM, JS HANAN \& P PRUSINKIEWICZ (1996) Virtual plants: new perspectives for ecologists, pathologists and agricultural scientists. Trends in Plant Science 1: 33-38.

SACK L, T MARANON \& PJ GRUBB (2002) Global allocation rules for patterns of biomass partitioning. Science 296: 1923

SINOQUET H, S THANISAWANYANGKURA, H MABROUK \& P KASEMSAP (1998) Characterization of the light environment in canopies using 3D digitising and image processing. Annals of Botany 82: 203-212.

SOKAL RR \& FJ ROHLF (1995) Biometry: the principles and practice of statistics in biological research. Third edition. W.H. Freeman \& Co., New York, New York, USA. 887 pp.

STENBERG P (1995) Penumbra in within-shoot and between-shoot shading in conifers and its significance for photosynthesis. Ecological Modelling 77: 215-231.

TAKENAKA A (1994) Effects of leaf blade narrowness

Associate Editor: Luis Corcuera

Received April 19, 2006; accepted May 15, 2006 and petiole length on the light capture efficiency of a shoot. Ecological Research 9: 109-114.

VALLADARES F \& RW PEARCY (1998) The functional ecology of shoot architecture in sun and shade plants of Heteromeles arbutifolia M. Roem, a California chaparral shrub. Oecologia 114: 1-10.

VALLADARES F, JB SKILLMAN \& RW PEARCY (2002) Convergence in light capture efficiencies among tropical forest shade tolerant plants with contrasting crown architectures: a case of morphological compensation. American Journal of Botany 89: 1275-1284.

WALTERS MB, EL KRUGER \& PB REICH (1996) Relative growth rate in relation to physiological and morphological traits for northern hardwood tree seedlings: species, light environment and ontogenetic considerations. Oecologia 96: 219-231.

WARTON DI \& NC WEBER (2002) Common slope tests for bivariate structural relationships. Biometrical Journal 44: 161-174. 